\title{
Continuous-Flow Biochemical Reactors: Biocatalysis, Bioconversion, and Bioanalytical Applications Utilizing Immobilized Microfluidic Enzyme Reactors
}

\author{
Laszlo Hajba $^{1}$ and Andras Guttman ${ }^{1,2 *}$ \\ ${ }^{1}$ MTA-PE Translational Glycomics Research Group, University of Pannonia, Veszprem, Hungary \\ ${ }^{2}$ Horvath Csaba Laboratory of Bioseparation Sciences, University of Debrecen, Debrecen, Hungary
}

Received: 22 June 2015; accepted: 24 August 2015

\begin{abstract}
The utilization of continuous-flow biochemical reactors, including biocatalysis, biotransformation, and biochemical interaction based flow-analytical systems, and enzyme reactors are recently the focus of attention to produce fine biochemicals and also show great potential in bioanalytical applications. Continuous-flow biochemical processes implemented in microstructured reactors enable short development time to production scale utilizing enzymatic processes to efficiently fulfill the current needs of the fine biochemical and pharmaceutical industry. Immobilization of the enzymes is preferable because it usually enhances their stability, and in some instances, immobilized enzymes can even be reused multiple times. In this review on the continuous-flow biochemical reactors, first the enzyme immobilization strategies will be briefly discussed followed by summarizing the recent developments in the field of immobilized enzyme microflow reactors for biocatalysis, bioconversion and bioanalytical purposes.
\end{abstract}

Keywords: continuous-flow biochemical reactor, enzyme immobilization, microreactors, biocatalysis, bioconversion, bioanalytics

\section{Introduction}

The utilization of continuous-flow biochemical reactors, including bioconversion, biocatalysis, biotransformation, and biochemical interaction based flow-analytical systems, and continuous-flow enzyme reactors are gaining high relevance in the production of specialty fine chemicals, drugs, biotherapeutics, and biofuels $[1,2]$. They also have high potential in bioanalytical applications, e.g., in genomics, proteomics, metabolomics, and glycomics [3]. Some of the main advantages of enzymatic processes are their high selectivity, operation under mild conditions (atmospheric pressure, relatively low temperature comparing to other catalysts), environmental friendliness (biodegradable), and high catalytic efficiency [4]. However, enzyme reactors may suffer from enzyme stability related issues, emphasizing the need for enzymatic process engineering. Microreactor technologies and enzyme immobilization are the most promising avenues for such development [5]. Enzymes immobilization is preferable in biochemical reactions because it usually enhances their stability, and in most instances, immobilized enzymes can be reused multiple times. Based on reusability, the costs of enzymatic reactions are reduced, extending their applicability in the production of fine biochemica biologics, and even biofuels [6]. Enzyme reactors can be scaled down to as little as microfluidic reaction devices, i.e., microchip-type microreactors (made by microfabrication techniques, e.g., photolithography) or microcapillary devices for continuous-flow production mode. Microfluidic devices feature large surface to volume ratios, require only micro- or nanoliter volumes of reagent solutions, offer high efficiency and repeatability [5], and last but not the least, scale out option by parallelization. Continuous-flow chemical processing (CFCP) in microfluidic devices is based on a combination of microunit operations (MUOs) like mixing, reaction, extraction, etc. During the microreactor design CFCP microchips are built as a combination of different MUOs [7].

Continuous-flow biochemical processes with conventional reactor systems, like packed bed reactors, had their limitations in mass and heat transfer $[8,9]$. Several articles were published about the design and optimization of such systems [10-13]. Microreactor technology could support enzymatic processes to efficiently fulfill the current needs of rapid process development in the biochemical and pharmaceutical industry, because microstructured continuous-

\footnotetext{
* Author for correspondence: a.guttman@neu.edu
}

flow reactors enable shorter development time to production scale [14]. Enhanced mass and heat transfer provided by continuous-flow microreactors can be utilized in process intensification, especially during multiphase biocatalytic processes. Miniaturization can also accelerate enzymatic reactions due to decreased diffusion limitation, resulting in reduced production time [15]. Through the scaleout option, microreactor technology is an option for industrial scale production, especially for hazardous reactions and/or materials (e.g., exothermic reactions, high-temperature reactions, reactions with unstable intermediates) that do not allow conventional reactor scale up. [16]. Parallel scale-out of microreactors enables highthroughput operation and can be readily applied to combinatorial processing $[17,18]$. However, despite of all advantages of microfluidic reactors, scale-out (numbering up) by parallelization is still challenging, because thousands of microreactor units are needed to reach industrial scale production rate $(\mathrm{kg} / \mathrm{min})$ and complex control systems are required to ensure identical operating conditions in each unit. On the other hand, conventional scale-up of microreactors by increasing in channel size risks their mass and heat transfer efficiency. The alternative solution is to find an intermediate scale device (e.g., in millimeter scale) that still ensures enhanced mass and heat transport rates while increasing production rate by parallelization of a reasonable number of reactor units $[19,20]$. The Advanced-Flow ${ }^{\mathrm{TM}}$ Reactor system from Corning and the MR-A5 ${ }^{\mathrm{TM}}$ and MR-A6 ${ }^{\mathrm{TM}}$ Reactor systems from Lonza are some of the commercially available solutions applicable for such purposes [21-23].

In this review on continuous-flow biochemical reactors, first, the major enzyme immobilization strategies will be briefly discussed, followed by summarizing the recent developments in the field of immobilized enzyme microflow reactors for biocatalysis (i.e., enzyme-catalyzed production of fine chemicals, drugs, and biopolymers) and bioanalytical purposes.

\section{Enzyme Immobilization Techniques for Continuous-Flow Operation}

Immobilization may cause slight distortions in the enzyme structure affecting the final properties of the enzyme, namely, activity, specificity, and selectivity [24, 25]. However, immobilization of enzymes comes with the following advantages: (1) enhanced stability, (2) option of repeated or continuous use, and 
(3) easy partitioning from the reaction mixture [26]. Therefore, proper enzyme immobilization for continuous-flow operation is of high importance to increase the efficiency of the enzymatic reaction. The most fundamental immobilization techniques are entrapment, adsorption, covalence, affinity, and cross-linking as

F1 depicted in Figure 1 [27]. Jones et al. developed an entrapment method, where enzymes were immobilized by incorporating them directly into the microchannel material [28]. The so-called "bioplastic" was prepared by mixing urease enzyme, polydimethylsiloxane (PDMS) monomer, and the curing agent. Curing was accomplished at room temperature to preserve the viability of the enzyme. The bioplastic contained approximately $0.5-$ $2.5 \mathrm{wt} \%$ urease resulting in a clear, flexible material suitable for molding into a microreactor device. Adsorption of the enzymes relies on weak bonds like Van der Waal's or electrostatic interaction. Liu et al. developed a method based on electrostatic interaction, where the enzyme was immobilized on a positively charged surface [29]. In the case of covalent binding (covalence), the supporting material is functionalized with an active group (e.g., amine, epoxy, etc.) and the enzymes are covalently bonded to the surface through them [30, 31]. Affinity tags that are present or added at a specific position far from the active site of the enzyme are capable to form strong affinity bonds between the enzyme and a surface functionalized with the complementary affinity ligand. Through the affinity bond, enzymes could be immobilized by site-specific and oriented manners [32]. As a carrier free immobilization technique, cross-linked enzyme aggregates (CLEA) recently gained interest because of their simplicity, great stability, and high activity [33]. These aggregates are usually prepared via glutaraldehyde crosslinking [34]. Immobilization techniques can also be classified based on their reaction location. One of the methods is direct immobilization onto the microchannel wall. Another approach utilized enzyme immobilization on a solid support inside the microchannel, e.g., on micro- and nanoparticles [35], porous polymer monoliths $[36,37]$ or membranes [38]. Recently, paramagnetic nanoparticles are also gaining attention because of their easy manipulation with a permanent magnet [39, 40].

\section{Continuous-Flow Biochemical Microreactors for Biocatalysis and Bioconversion}

Microfabricated flow reactor systems with immobilized enzymes are of great recent importance in the biopharmaceutical industry, namely, in the production of specific antibiotics, highly toxic antitumor drugs [41, 42], or drug delivery agents

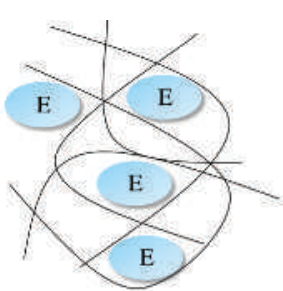

Entrapment
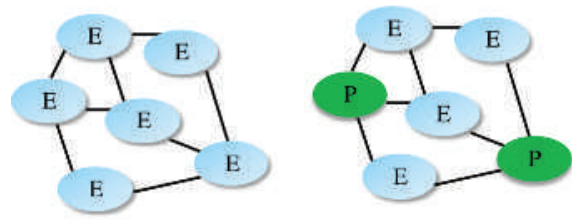

Cross-linking

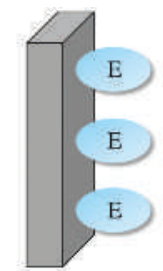

Adsorption

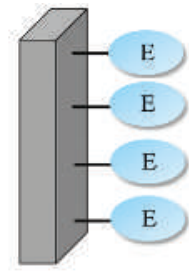

Covalence

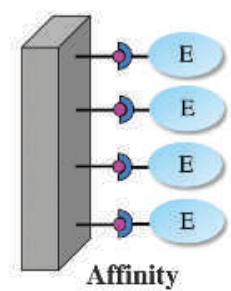

Figure 1. Fundamental enzyme immobilization techniques. E: enzyme, P: inert protein. Reproduced with permission from [26]. ${ }^{(} 2012$ Elsevier
[43]. The main applications of continuous-flow biochemical microreactor systems utilizing immobilized enzymes for bioconversion are summarized in Table 1 . The use of enzymatic T1 processes for bioconversion of common raw materials is continuously increasing. For example, nitrobenzene is a common starting material for several dye and drug molecules like phenoxazine. Phenoxazine and its derivatives have antitumor activity because they inhibit the DNA-dependent RNA polymerase through intercalation into the DNA strands of malignant cells [44]. Spain and coworkers developed a microfluidics based multistep chemoenzymatic process for the continuous production of 2-aminophenoxazine-3-one from nitrobenzene substrate [41]. The enzymes of hydroxylaminobenzene mutase and soybean peroxidase were encapsulated in polyethyleneimine mediated silica microparticles and packed in two separate fused silica capillaries. The complete chemoenzymatic platform was constructed in a metallic zinc chip and the two serially connected enzyme capillary microreactors, as depicted in Figure 2. F2 The chemoenzymatic flow-through system ensured rapid conversion of the nitrobenzene substrate and was also capable of efficient bioconversion of other nitroarenes.

Cyclodextrins (CDs) with lipophilic inner cavities and hydrophilic outer surfaces can act as drug delivery vehicles due to their capability to interact with different drug molecules via inclusion complexation [45]. An immobilized enzyme microreactor system was developed for the continuous production of $\beta$-cyclodextrin from starch by Schöffer et al. [43]. Cyclodextrin glycosyltransferase (CGTase) was immobilized on the surface of glutaraldehyde-activated chitosan spheres, and the microparticles were packed into a glass tube. The developed immobilized microfluidic enzymatic reactors featured very high operational stability, and the immobilized CGTase retained its initial activity even after $100 \mathrm{~h}$ of continuous use. In the field of green chemistry, it is really important to use renewable raw materials as substrates. Bakonyi and coworkers produced isoamyl oleate, a biolubricant, from renewable sources with continuous enzymatic reaction in a microreactor system (H-Cube ${ }^{\mathrm{TM}}$ and X-Cube ${ }^{\mathrm{TM}}$ from ThalesNano) [46]. Lipase B was immobilized on an acrylic resin (Novozyme 435), and the enzyme functionalized resin was packed into the CatCart ${ }^{\mathrm{TM}}$ catalyst cartridge yielding a conversion rate of $98 \%$.

\section{Bioanalytical Applications}

One of the fastest growing bioanalytical fields these days are in the so-called omics areas, including genomics, proteomics, metabolomics, and glycomics. In proteomics, for example, the key sample preparation step is protein digestion with proteases such as trypsin, chymotrypsin, etc. [3]. With the use of immobilized enzymes, enzyme-to-substrate ratios can be increased, speeding up digestion times and reducing autolysis compared to traditional proteolytic digestion in aqueous solutions. Waldron and coworkers immobilized chymotrypsin on the wall of a fused-silica capillary [30]. The resulting immobilized microfluidic enzyme reactor (IMER) produced good results in myoglobin digestion and $83 \%$ sequence coverage was achieved by capillary electrophoresis-mass spectrometry (CE-MS) peptide mass mapping following the digestion process. An interesting enzyme immobilization approach was introduced by Safdar et al. by fabricating an open tubular flow-microreactor with trypsin immobilized gold nanoparticles attached to the inner wall of a fused silica capillary [50]. For cytochrome C substrate, the MS sequence coverage of the resulting peptide mixture was above $75 \%$. The activity of the immobilized enzyme remained apparently the same after several repeated digestion steps proving the high stability of the flow-microreactor even in repeated 
Table 1. Continuous-flow biochemical microreactor systems with immobilized enzymes for bioconversion

\begin{tabular}{|c|c|c|c|c|}
\hline Support & Immobilization technique & Enzyme & Applications & References \\
\hline Silica microparticles & $\begin{array}{l}\text { Enzyme was encapsulated in } \\
\text { polyethyleneimine mediated } \\
\text { silica microparticles packed } \\
\text { into a fused-silica capillary. }\end{array}$ & $\begin{array}{l}\text { Hydroxylaminobenzene } \\
\text { mutase, soybean } \\
\text { peroxidase, nitrobenzene } \\
\text { nitroreductase }\end{array}$ & $\begin{array}{l}\text { Production of antitumor } \\
\text { and antibiotic drugs }\end{array}$ & {$[41,42]$} \\
\hline Acrylic resin & $\begin{array}{l}\text { Enzyme was immobilized on } \\
\text { octadecyl-activated acrylic resin } \\
\text { by hydrophobic interaction. } \\
\text { The microparticles were packed into } \\
\left.\text { a stainless steel tube (CatCart }{ }^{\mathrm{TM}}\right) \text {. }\end{array}$ & $\begin{array}{l}\text { Lipase B } \\
\text { (Novozyme 435) }\end{array}$ & $\begin{array}{l}\text { Biolubricant } \\
\text { production from } \\
\text { renewable raw materials }\end{array}$ & [46] \\
\hline $\begin{array}{l}\text { Eupergit }{ }^{\mathrm{TM}} \text { oxirane } \\
\text { acrylic microparticles }\end{array}$ & $\begin{array}{l}\text { Enzyme was immobilized covalently } \\
\text { through the Eupergit epoxy group } \\
\text { without the need for additional } \\
\text { reagents. The microparticles were } \\
\text { packed into a glass tube. }\end{array}$ & $\begin{array}{l}\text { Threonine } \\
\text { aldolase (TA) }\end{array}$ & $\begin{array}{l}\text { Production of } \\
\text { phenylserine }\end{array}$ & [47] \\
\hline Chitosan spheres & $\begin{array}{l}\text { Enzyme was immobilized on the } \\
\text { surface of chitosan spheres with } \\
\text { glutaraldehyde. The microparticles } \\
\text { were packed into a glass tube. }\end{array}$ & $\begin{array}{l}\text { Cyclodextrin } \\
\text { glycosyltransferase } \\
\text { (CGTase) }\end{array}$ & $\begin{array}{l}\text { Production of } \\
\beta \text {-cyclodextrin } \\
\text { from starch }\end{array}$ & [43] \\
\hline $\begin{array}{l}\text { Macroporous } \\
\text { wash-coatlayer } \\
\text { of } \gamma \text {-aluminum oxide }\end{array}$ & $\begin{array}{l}\text { The macroporous aluminum oxide layer } \\
\text { on the stainless steel microchannels } \\
\text { was functionalized with APTES, } \\
\text { and the enzyme was cross-linked } \\
\text { to the functionalized surface } \\
\text { with glutaraldehyde. }\end{array}$ & $\beta$-Glycosidase & Hydrolysis of lactose & [48] \\
\hline $\begin{array}{l}\text { Epoxy-activated } \\
\text { monolithic } \\
\text { Convective Interaction } \\
\text { Media }(C I M()) \text { disk }\end{array}$ & $\begin{array}{l}\text { Enzyme was immobilized covalently } \\
\text { through the epoxy group without } \\
\text { the need of any additional reagents. }\end{array}$ & Glucuronan lyase & $\begin{array}{l}\text { Production of } \\
\text { oligoglucuronans }\end{array}$ & [49] \\
\hline Nylon membrane & $\begin{array}{l}\text { Hydrochloric acid was used to activate the } \\
\text { amino groups on the membrane surface. } \\
\text { After that, the enzyme was cross-linked } \\
\text { to the membrane surface with glutaraldehyde. }\end{array}$ & Horseradish peroxidase & Production of dyes & [38] \\
\hline
\end{tabular}

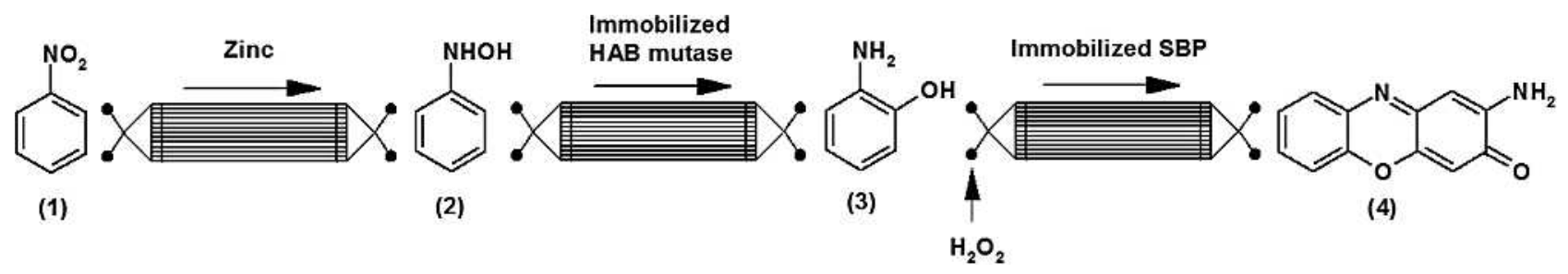

Figure 2. Multi-step continuous-flow chemoenzymatic process for the bioconversion of nitrobenzene. Reproduced with permission from Woitalka et al. (2014) [19]. ${ }^{\text {2}} 2007$ John Wiley and Sons

usage. Zhang and coworkers fabricated an immobilized continuous-flow enzyme microreactor using trypsin functionalized magnetic microparticles [51]. The microflow reactor was successfully applied for the on-line digestion of the cytochrome $\mathrm{C}$ and BSA. In comparison to solution based digestion, similar sequence coverages were achieved, but within much shorter

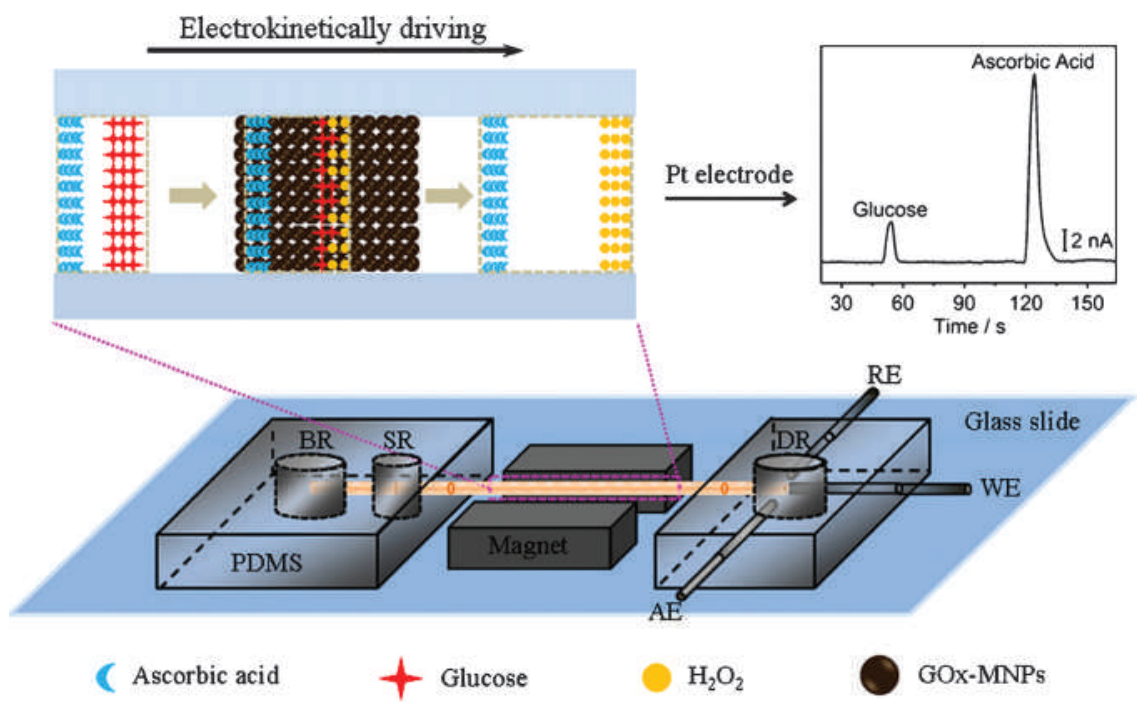

Figure 3. Schematic representation of a continuous-flow bioanalytical microdevice using glucose peroxidase functionalized magnetic nanoparticles for amperometric detection of glucose. Reproduced with permission from Miyazaki and Maeda (2006) [18]. ${ }^{\circ} 2012$ Elsevier 


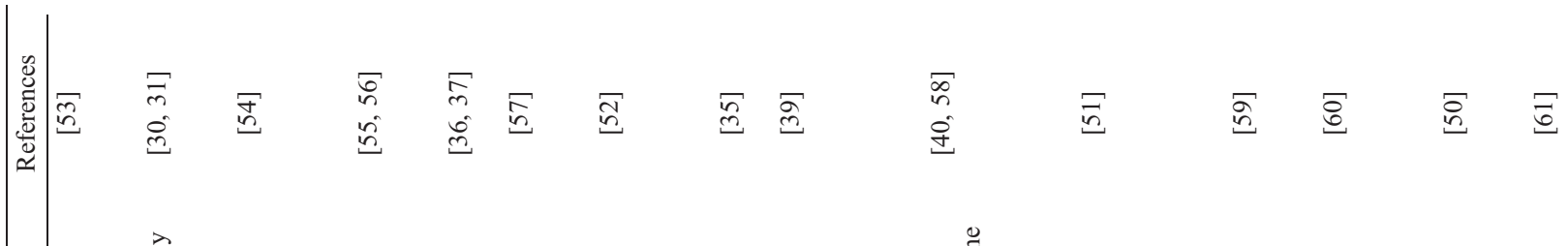

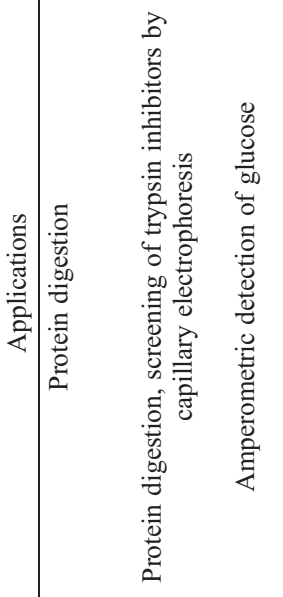

$$
\begin{aligned}
& \|\| \| \\
& \text { In } \\
& \text { II Mn }
\end{aligned}
$$
Mun

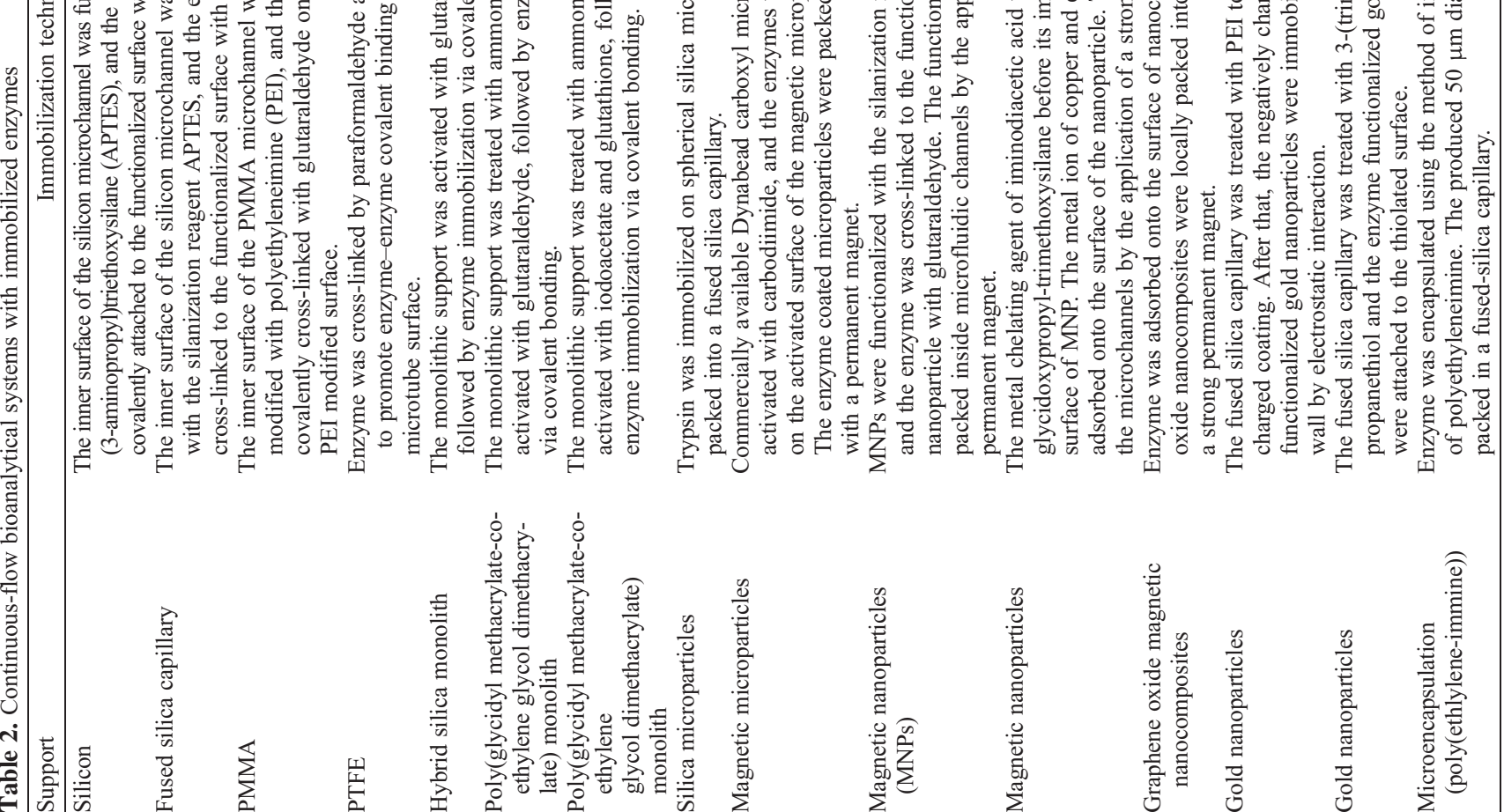


processing times. The main advantages of the use of magnetic nanoparticles were easy manipulation with an external magnetic field within the microchannel and the trypsin functionalized magnetic nanoparticles could be easily regenerated. Krenkova et al. developed an immobilized enzyme flow-microreactor for rapid and effective release of $\mathrm{N}$-glycans from glycoproteins [52]. The PNGase F enzyme was immobilized on the methacrylatebased porous monolithic support through GST-glutathione coupling. Most importantly, the oriented PNGase F immobilization approach they used resulted in significantly higher enzymatic activity and the immobilized enzyme remained stable for several months.

Blood glucose is an important marker in diabetes. Ju and coworkers developed a continuous-flow microfluidic device for F3 amperometric detection of glucose as shown in Figure 3 [40]. Magnetic nanoparticles were functionalized with glucose peroxidase, introduced into the capillary of a microfluidic device and held there by two permanent magnets (magnets were shorter than the capillary). With increasing enzyme reactor length (packed length with magnetic nanoparticles), which was tuned by changing the length of the magnets, the detection limit improved. The glucose concentration of four human serum samples determined by the microfluidic device showed good agreement with spectrophotometric control measurements. The main bioanalytical applications of immobilized enzyme microT2 reactors are summarized in Table 2.

\section{Conclusions and Future Perspectives}

The utilization of continuous-flow biochemical systems offers excellent bioprocess intensification and very efficient bioanalytical tools. Immobilized enzyme microreactors support "green" production of biomaterials and pharmaceutical products with excellent yield and high efficiency. Reaction conditions optimized for a single microreactor unit can be adapted to larger scale production by parallelization (scale out); however, this process requires careful attention of complex control systems that required ensuring identical operating conditions of the units. New discoveries in nanotechnology and the advent of novel solid support materials such as carbon nanomaterials advanced enzyme immobilization development by allowing higher enzyme load on solid supports. On the other hand, the microfluidic approach offers great potential for further development by the utilization of their inherently large surface to volume ratios. Specific geometric design of the microfluidic channels may also increase the contact efficiency between the fluid flow and the enzyme containing solid support (e.g., microchannel wall, beads, etc.). Enzyme microreactors will also find their way in specific biomedical applications as point-of-care microfluidic devices for continuous monitoring of disease state.

Acknowledgment. The support of the Momentum grant no. 97101 of the Hungarian Academy of Sciences (MTA-PE Translational Glycomics) is gratefully acknowledged.

\section{References}

1. Panke, S.; Held, M.; Wubbolts, M. Curr. Opin. Biotechnol. 2004, 15, 272 2. Noraini, M. Y.; Ong, H. C.; Badrul, M. J.; Chong, W. T. Renewable Sustainable Energy Rev. 2014, 39, 24 ^

28,85 A

3. Monzo, A.; Sperling, E.; Guttman, A. TrAc, Trends Anal. Chem. 2009.

4. Fernandes, P. Int. J. Mol. Sci. 2010, 11, 858

5. Asanomi, Y.; Yamaguchi, H.; Miyazaki, M.; Maeda, H. Molecules 2011 , 16,604 A

6. Franssen, M. C. R.; Steunenberg, P.; Scott, E. L.; Zuilhof, H.; Sanders, J. P. M. Chem. Soc. Rev. 2013, 42, 649

7. Tokeshi, M.; Minagawa, T.; Uchiyama, K.; Hibara, A.; Sato, K.; Hisamoto, H.; Kitamori, T. Anal. Chem. 2002, 74, 1565

8. Miyazaki, M.; Honda, T.; Yamaguchi, H.; Briones, M. P. P.; Maeda, H. Biotechnol. Genet. Eng. Rev. 2008, 25, 40Д
9. Losey, M. W.; Schmidt, M. A.; Jensen, K. F. Ind. Eng. Chem. Res. 2001, 40,2555

10. Webb, C.; Kang, H. K.; Moffat, G.; Williams, R. A.; Estevez, A. M.; Cuellar, J.; Jaraiz, E.; Galan, M. A. Chem. Eng. J. Biochem. Eng. J. 1996, 61, 24 A

11. Vos, H. J.; Luyben, K. C. A. M.; Westerterp, K. R. Chem. Eng. J. Biochem. Eng. J. 1993, 53, Bh

12. Chen, H. C.; Ju, H. Y.; Wu, T. T.; Liu, Y. C.; Lee, C. C.; Chang, C.; Chung, Y. L.; Shieh, C. J. J. Biomed. Biotechnol. 2011

13. Ronne, T. H.; Yang, T. K.; Mu, H. L.; Jacobsen, C.; Xu, X. B. J. Agric. Food Chem. 2005, 53, 561 $九$

14. Bolivar, J. M.; Nidetzky, B. Green Process. Synth. 2013, 2, 54h

15. Tanaka, Y.; Slyadnev, M. N.; Sato, K.; Tokeshi, M.; Kim, H. B.; Kitamori,

T. Anal. Sci. 2001, 17, 809

16. Zhang, X. N.; Stefanick, S.; Villani, F. J. Org. Process Res. Dev. 2004, 8, 455 333.

17. Bolivar, J. M.; Wiesbauer, J.; Nidetzky, B. Trends Biotechnol. 2011, 29,

18. Miyazaki, M.; Maeda, H. Trends Biotechnol. 2006, 24, 463A

19. Woitalka, A.; Kuhn, S.; Jensen, K. F. Chem. Eng. Sci. 2014, 116, h

20. Nieves-Remacha, M. J.; Kulkarni, A. A.; Jensen, K. F. Ind. Eng. Chem. Res. 2012, 51, 1625

21. Dann, E.; Schmidt, F.; Chevalier, B. Chim. Oggi 2009, 27, 12

22. Kockmann, N.; Gottsponer, M.; Zimmermann, B.; Roberge, D. M. Chem. - Eur. J. 2008, 14, 7470

23. Zhang, F.; Cerato-Noyerie, C.; Woehl, P.; Lavric, E. D. Chem. Eng. Trans. 2011, 24, 1369

24. Rodrigues, R. C.; Ortiz, C.; Berenguer-Murcia, A.; Torres, R.; FernandezLafuente, R. Chem. Soc. Rev. 2013, 42, 6290

25. Mateo, C.; Palomo, J. M.; Fernandez-Lorente, G.; Guisan, J. M.; Fernandez-Lafuente, R. Enzyme Microb. Technol. 2007, 40, 145 h

26. Bornscheuer, U. T. Angew. Chem., Int. Ed. 2003, 42, 3336

27. Sassolas, A.; Blum, L. J.; Leca-Bouvier, B. D. Biotechnol. Adv. 2012, 30, 489

28. Jones, F.; Lu, Z. H.; Elmore, B. B. Appl. Biochem. Biotechnol. 2002, 98, 62 ᄀ

29. Liu, C.; Zhang, Q.; Kang, J. Methods Mol. Biol. 2013, 984, 321 ^ 1804

30. Ghafourifar, G.; Fleitz, A.; Waldron, K. C. Electrophoresis 2013, 34,

31. Min, W. N.; Cui, S. M.; Wang, W. P.; Chen, J. R.; Hu, Z. D. Anal. Biochem. 2013, 438, 32A

32. Sassolas, A.; Hayat, A.; Marty, J. L. Methods Mol. Biol. 2013, 1051, 139^ 33. Cao, L. Q. Curr. Opin. Chem. Biol. 2005, 9, 217 ^

34. Barbosa, O.; Ortiz, C.; Berenguer-Murcia, A.; Torres, R.; Rodrigues, R.

C.; Fernandez-Lafuente, R. RSC Adv. 2014, 4, 1583A

35. Liu, L. N.; Zhang, B.; Zhang, Q.; Shi, Y. H.; Guo, L. P.; Yang, L. J. Chromatogr. A 2014, 1352, 80A

36. Wang, T.; Ma, J.; Wu, S.; Yuan, H.; Zhang, L.; Liang, Z.; Zhang, Y. Electrophoresis 2011, 32, 2848

37. Wang, T. T.; Ma, J. F.; Zhu, G. J.; Shan, Y. C.; Liang, Z.; Zhang, L. H.; Zhang, Y. K. J. Sep. Sci. 2010, 33, 3194^

38. Hisamoto, H.; Shimizu, Y.; Uchiyama, K.; Tokeshi, M.; Kikutani, Y.; Hibara, A.; Kitamori, T. Anal. Chem. 2003, 75, 350^

39. Shi, J.; Zhao, W. W.; Chen, Y. F.; Guo, L. P.; Yang, L. Electrophoresis 2012, 33, 2145n

40. Sheng, J.; Zhang, L.; Lei, J. P.; Ju, H. X. Anal. Chim. Acta 2012, 709, 41^ 41. Luckarift, H. R.; Ku, B. S.; Dordick, J. S.; Spain, J. C. Biotechnol. Bioeng. 2007, 98, 701A

42. Berne, C.; Betancor, L.; Luckarift, H. R.; Spain, J. C. Biomacromolecules 2006, 7, 2631^

43. Schoffer, J. D.; Klein, M. P.; Rodrigues, R. C.; Hertz, P. F. Carbohydr. Polym. 2013, 98, 1311

44. Koshibu-Koizumi, J.; Akazawa, M.; Iwamoto, T; Takasaki, M.; Mizuno, F.; Kobayashi, R.; Abe, A.; Tomoda, A.; Hamatake, M.; Ishida, R. J. Cancer Res. Clin. Oncol. 2002, 128, 363A

45. Tiwari, G.; Tiwari, R.; Rai, A. K. J. Pharm. BioAllied Sci. 2010, 2, 72^

46. Madarasz, J.; Nemeth, D.; Bakos, J.; Gubicza, L.; Bakonyi, P. J. Cleaner

Prod. 2015, 93, 140

47. Tibhe, J. D.; Fu, H.; Noel, T.; Wang, Q.; Meuldijk, J.; Hessel, V. Beilstein

J. Org. Chem. 2013, 9, 2168^

48. Thomsen, M. S.; Nidetzky, B. Biotechnol. J. 2009, 4, 98^

49. Tavernier, M. L.; Petit, E.; Delattre, C.; Courtois, B.; Courtois, J.;

Strancar, A.; Michaud, P. Carbohydr. Res. 2008, 343, 2687

50. Safdar, M.; Spross, J.; Janis, J. J. Mass Spectrom. 2013, 48, 1281^

51. Li, Y.; Xu, X. Q.; Yan, B.; Deng, C. H.; Yu, W. J.; Yang, P. Y.; Zhang, X. M. J. Proteome Res. 2007, 6, 2367^

52. Krenkova, J.; Szekrenyes, A.; Keresztessy, Z.; Foret, F.; Guttman, A. J. Chromatogr. A 2013, 1322, 54^

53. Ekstrom, S.; Onnerfjord, P.; Nilsson, J.; Bengtsson, M.; Laurell, T.; Marko-Varga, G. Anal. Chem. 2000, 72, 286A

54. Ferreira, L. M. C.; da Costa, E. T.; do Lago, C. L.; Angnes, L. Biosens. Bioelectron. 2013, 47, 539^

55. Yamaguchi, H.; Miyazaki, M.; Honda, T.; Briones-Nagata, M. P.; Arima, K.; Maeda, H. Electrophoresis 2009, 30, 3257^

56. Yamaguchi, H.; Miyazaki, M.; Kawazumi, H.; Maeda, H. Anal. Biochem. 2010, $407,12 \AA$

57. Duan, J. C.; Liang, Z.; Yang, C.; Zhang, J.; Zhang, L. H.; Zhang, W. B.; Zhang, Y. K. Proteomics 2006, 6, 412

58. Yu, D. H.; Van Antwerpen, P.; Patris, S.; Blankert, B.; Kauffmann, J. M. Comb. Chem. High Throughput Screening 2010, 13, 455^

59. Liang, R. P.; Wang, X. N.; Liu, C. M.; Meng, X. Y.; Qiu, J. D. J. Chromatogr. A 2013, 1315, 28^

60. Lin, P. T.; Zhao, S. L.; Lu, X.; Ye, F. G.; Wang, H. S. J. Sep. Sci. 2013, 36, $2538 \wedge$

61. Roman-Gusetu, G.; Waldron, K. C.; Rochefort, D. J. Chromatogr. A 2009, 1216, 8270A 